\title{
The Effects of Exogenous Bioregulators and Environment on Regular Cropping of Apple
}

Kathleen M. Williams ${ }^{1}$ and Esmaeil Fallahi ${ }^{2}$

AdDITIONAL INDEX WORDS. apple chemical thinning, apple growth regulators, crop load, blossom thinning, Malus $\times$ domestica, postbloom thinning

SummaRY. The use of exogenous plant bioregulators or plant hormones to adjust crop load in apple (Malus $\times$ dometica Borkh.) and promote regular cropping remains challenging to both researchers and producers. Responses to these hormones are sensitive to the rate and timing of application, to physiological status of the tree, orchard system, variety, rootstock, and a myriad of cultural practices and environmental factors. Of the environmental factors, temperature plays the most important role in determining response and efficacy of a given material. All classes of plant bioregulators have been used over the past $\mathbf{3 0}$ to $\mathbf{4 0}$ years as postbloom chemical thinning materials. M ost of the standard postbloom thinning programs involve application of a synthetic auxin, such as naphthalene acetic acid (N AA) in combination with carbaryl (Sevin), a commonly used insecticide. The mode of action of these two compounds is not clearly understood. G ibberellins generally have not been effective thinning materials for apple because of their negative impact on return bloom. E thylene-releasing compounds have been used successfully as postbloom thinning materials. Cytokinins, particularly synthetic sources such as 6-benzyladenine (6-BA), have been shown to effectively thin fruit and enhance fruit size on many commercial varieties. The rate and timing of 6-BA applications are critical to obtain desirable thinning and fruit size responses. The use of these different bioregulators is essential for regular cropping of apple, particularly for spur 'D elicious', 'Fuji' and other varieties that are difficult to thin chemically and which are prone to severe alternate bearing. The focus of this discussion is the use of these bioregulators in commercial apple production areas in the U nited States.

\section{A}

pple trees are noted for setting more fruit than is needed for commercial harvest. If not properly thinned by flower or fruit removal the trees will develop an alternate or biennial bearing habit. O vercropping of trees, especially during the early years of establishment and production, can reduce carbohydrate reserves needed for vegetative growth and flower bud formation for next year's crop (Williams, 1994a). O vercropping results in too many small fruit because of competition for photosynthates between the developing fruit, as well as competition between vegetative growth and fruit development. These small fruit are generally undesirable in the marketplace, since fresh market apples are graded and sold on the basis of size and external color. Thus, biennial bearing has an impact on the economic survival of apple producers, as well as fruit warehouses. (Williams, 1994a).

\footnotetext{
The cost of publishing this paper was defrayed in part by the payment of page charges. U nder postal regulations, this paper therefore must be hereby marked advertisement solely to indicate this fact. 
Chemical removal of fruit is necessary for both labor efficiency and reducing production costs. $\mathrm{H}$ and thinning is labor intensive and expensive. Also, fruit thinning by hand is generally not conducted early enough in the growing season to negate effects of excessive flowering and fruit set.

Early removal of potential fruit (blossom thinning) is currently used experimentally or on a commercialscale in many apple producing areas to enhanceflower initiation for next year's crop and thus, return bloom (Fallahi, 1997; Fallahi et al., 1997), and to reduce competition for photosynthates. Blossom thinnersusually havea caustic effect on floral parts. $\mathrm{N}$ ew blossom thinners include sulfcarbamide (Wilthin) (Williams, 1994b, Fallahi et al., 1997), endothallicacid (Endothall), and pelargonic acid (Thinex) (Williams, 1994b; Fallahi, 1997), and hydrogen cyanamide (D ormex) (Fallahi, 1997; Fallahi et al., 1997, 1998).

The practice of postbloom thinning, generally from 3 to $18 \mathrm{~mm}(0.12$ to 0.71 inch) fruit size, is used to promote return bloom, as well as to regulate crop load. H owever, fruit removal which occurs after the period of flower initiation, generally 30 to $45 \mathrm{~d}$ after full bloom, will affect crop load only. For this reason, hand thinning is used to balance crop load and to improve fruit size, rather than influence flower initiation.

The use of naphthalene acetic acid (N AA), a synthetic auxin, gained acceptance in the 1950s and 1960s. Another synthetic auxin, naphthal ene-acetamide (NAD), was found to be suitable for postbloom thinning of many commercial applevarieties(Westwood and Batjer, 1964). In the 1960s, carbaryl (Sevin), a commonly used insecticide, was introduced as a postbloom thinner (Williams, 1994a). In the 1970s combinations of carbaryl and NAA, or carbaryl and NAD, were adopted as commercially acceptable postbloom thinning sprays. Also, in the 1970s most of the other plant bioregulators, i.e., gibberellins, cytokinins, and ethyleneweretested for both pome and stone fruit thinning. In the 1980s, synthetic cytokinins such as6-benzyladenine (6-BA) wereused in chemical thinning experiments. Interest in finding consistent postbloom thinning materialscontinues into the $1990 \mathrm{~s}$ as all of the presently available materials have limitations imposed by rate or timing.
Further complicating the efficacy of postbloom thinning materials are the effects of environmental factors, particularly temperature and light levels. If cool, cloudy weather predominates during the fall, carbohydrate reserves may be reduced for the next spring (Byers et al., 1990). This lower level of reserves affects the vigor of the tree, perhaps even its survival during extremely cold winter stress periods. Lower carbohydrate reserves may so weaken the tree that bloom is erratic. Winter damage can affect the translocation of nutrients from the root system to the growing points during the subsequent spring. I f thereisconsiderable spur damage, flowering and fruit set will be diminished. And finally, temperatures during bloom influence the rate of bud emergence, as well as fruit set. If temperatures are warm during bloom, carbohydrate reserves are used at a faster rate than in a cool or normal bloom period. With fewer reserves available to both vegetative and fruit growth, fruit set and thus, yield, may be reduced. (Robinson et al., 1998; Williams and E dgerton, 1981).

Photosynthetic rate (and carbohydrate allocation) affects the amount of fruit set and the response to fruit thinning. Cultural practicesthat reducelight interception, such as poor pruning, will lower fruit set and yield (Byers et al., 1990; Lehman et al., 1987).

Naphthaleneacetic ACID AND OTHER SYNTHETIC AUXINS. The exact nature of NAA's mode of action is unclear. Several mechanisms appear to be involved in the fruit thinning response. It is thought that NAA (and other synthetic auxins) may increase the rate of metabolic activity of developing embryos. N AA may also stimulate ethylene biosynthesis when applied at relatively high rates. This endogenous ethylene may also decrease the photosynthetic rate (Robinson et al., 1998) and fruit growth rate. The inhibition of fruit growth is correlated with abscission of weaker fruit. Competition between fruit appears to be moderated by seed numbers, although the amount of thinning is not correlated with seed number per se (Williams, 1993).

Fruit size has generally been considered to be the most important factor for timing N AA application, with 7.5 to $10 \mathrm{~mm}$ (0.30 to 0.39 inch) being considered optimum for thinning response (R obinson et al., 1998;
Williams, 1999). However, Byers (1990) has shown that environmental factors, particularly temperature, are far more important than an exact fruit size in achieving a thinning response. Although temperature effectsmay differ slightly from the Pacific N orthwest to the northeastern $U$ nited States, it is generally suggested that NAA works most effectively, without the risk of overthinning, at 20 to $25{ }^{\circ} \mathrm{C}(\approx 70$ to $80{ }^{\circ} \mathrm{F}$ ).

D rying conditions after N AA application also may affect the response of the fruit tissue. I $\mathrm{f}$ relative humidity is low, and temperatures are warm $\left[>15^{\circ} \mathrm{C}\left(59^{\circ} \mathrm{F}\right)\right]$, drying of the spray is accelerated. Ebert and Kreuz (1988) found that with high rates of N AA [ 15 $\left.\mathrm{mg} \cdot \mathrm{L}^{-1}(\mathrm{ppm})\right]$ applied during warm weather, the absorption of the material decreased, particularly with low relative humidity. Addition of a wetting agent, such as Regulaid, to the spray solution slows the rate of drying and increases the uptake of N AA into leaf and fruit tissue (Westwood and Batjer, 1960).

In the Pacific N orthwest (PN W), N AA is used primarily as a postbloom thinning material for spur 'D elicious' at fruit sizes of 8 to $10 \mathrm{~mm}(0.32$ to 0.39 inch) at rates of 2 to $5 \mathrm{mg} \cdot \mathrm{L}^{-1}$ (Williams, 1999). N AA has not performed consistently as a blossom thinning material in the PNW, but has been found to be a mild blossomthinning material under northeastern conditions (Robinson et al., 1998). Relatively high temperatures during the bloom period in most areas of the PNW growing region allow use of lower rates of NAA for postbloom thinning. Rates of NAA that would be appropriate for the northeastern U .S. can cause excessive fruit thinning in the PNW. The faster drying conditions in the PN W are countered with the addition of a surfactant such as R egulaid. Temperatures are often in the 20 to $28{ }^{\circ} \mathrm{C}$ ( 68 to $82{ }^{\circ} \mathrm{F}$ ) range from full bloom through $20 \mathrm{~mm}(0.79$ inch) fruit size. The high light intensity and low relative humidity also affect the rates of NAA used for postbloom thinning of spur ' $D$ elicious'. When compared to postbloom thinning programs used in N ew York and $M$ ichigan, the rates of N AA used in the PN W are generally reduced by $50 \%$ (Williams, 1999; Schwallier, 1996; Robinson et al., 1998).

In M ichigan, rates of N AA in the 
10 to $20 \mathrm{mg} \cdot \mathrm{L}^{-1}$ range are suggested for most commercial varieties, with the easier to thin varieties (e.g., 'G ala', 'E mpire' and standard 'D elicious') requiring the $10 \mathrm{ppm}$ rate while difficult to thin varieties, such as 'Fuji' and 'Golden Delicious', require $20 \mathrm{ppm}$ NAA. In N ew York, 2.5 to $15 \mathrm{mg} \cdot \mathrm{L}^{-1}$ NAA isused for thinning (R obinson et al., 1998).

Excessive NAA may result in reduced fruit size, as well as abnormally small fruit called pygmy fruit. This negative effect on fruit size commonly occurs when the N AA is applied when the temperature is too cool (Williams, 1999) or too high (Robinson et al., 1998) or when fruit is too large, generally in excess of $20 \mathrm{~mm}$. I $\mathrm{n}$ thePN W, the risk of pygmy fruit formation in spur 'D elicious' is increased if N AA is applied when fruit size exceeds $15 \mathrm{~mm}$ (0.59 inch) in diameter. U nder northeastern conditions, pygmy fruit formation increases when fruit size exceeds $20 \mathrm{~mm}$ (0.79 inch). High rates of NAA may also reduce the rates of fruit growth in varieties, such as 'D elicious', 'Empire' and 'Gala'.

NAD is used commonly on varieties that are considered difficult to thin, such as 'Fuji' at rates of 25 to 50 $\mathrm{mg} \cdot \mathrm{L}^{-1}$ (Robinson et al., 1998; Schwallier, 1996; Williams, 1999). Like N AA, late applications often result in pygmy fruit formation. Both standard and spur 'D elicious' strains are sensitive to $N A D$ and excessive pygmy fruit formation may result from N AD applications. Generally, N AD is not used as a solo application; it is considered a relatively mild postbloom thinning material.

M CPB-ethyl, an ethyl ester of butyric acid (4-[4-chloro-2methylphenoxy]-butyric acid), another synthetic auxin, has been tested in British Columbia by Looney et al. (1998) as a potential postbloom thinning material for 'Fuji'. Carbaryl and NAA were shown to be more consistent than MCPB in postbloom response of 'Fuji' . Also, the lack of availability of M CBP in either Canada or the $U$.S. will limit its usefulness to the $\mathrm{N}$ orth A merican apple industry.

Carbaryl. Carbaryl (Sevin $X L R+$, Sevin $4 F$, carbaryl formulations), a carbamate, is the main postbloom thinning material used throughout the apple producing regions of the U .S. I t is considered to be arelatively safethinning material when used at the correct rates and timing, in that the risk of overthinning is minimal. The optimum timing for carbaryl is generally in the 8 to $10 \mathrm{~mm}(0.32$ to 0.39 inch) fruit size range, although petal fall ( 3 to $5 \mathrm{~mm}$ ) ( 0.12 to 0.20 inch) applications havealso been shown to be effective as well.

The rates for most carbaryl postbloom thinning programs in the $U$ nited States are 300 to $600 \mathrm{mg} \cdot \mathrm{L}^{-1}$. Carbaryl has not been shown to be a strongly rateresponsivematerial. D oubling or tripling the rate of carbaryl applied for fruit thinning does not double or triple the rate of thinning response (D ennis, 1996). O ptimum temperatures for thinning after a carbaryl application range from 15 to 25 ${ }^{\circ} \mathrm{C}\left(\approx 60\right.$ to $\left.80^{\circ} \mathrm{F}\right)$. A pple producers in the PN W have observed that carbaryl applied during cool weather may still thin fruit, albeit the response is considerably slower, whereas NAA will remain relatively ineffective during cool weather (Williams, 1993). H owever, carbaryl applied during cool weather mayincreasephytotoxic responses, such as fruit deformation in 'Bisbee' and 'V alleeSpur' strains of spur 'D elicious' (Williams, 1999).

The main drawback of carbaryl at the petal fall or early timing is its toxicity to bees. $\mathrm{H}$ owever, newer formulations, such as Sevin XL R +, haveminimal impact on bees due to the particle size technology used in the manufacturing process (D. M ayer, personal communication). C arbaryl isoften used in combination with NAA or NAD (Grausland, 1981; M icke et al., 1991; Robinson et al., 1998; Schwallier, 1996; Williams, 1999) to reduce rates and increase the effectiveness or synergy of both materials.

Combinations of carbaryl with 6BA have been used successfully in the northeastern U .S. for postbloom thinning of many commercial apple varieties (G reene and Autio, 1994; G reene et al., 1990; Elfving and Cline, 1993a, 1993b; Robinson et al., 1998; Schwallier, 1996). The thinning response of difficult to thin varieties such as spur 'D elicious' and 'Fuji' has been fairly consistent with carbaryl, but the addition of 6-BA does not increase the thinning response. The lack of a strong thinning response of spur 'D elicious' and 'Fuji' to 6-BA application, even in combination with carbaryl, suggests that the labelled rates are too low for warmer areas and for the varieties that are produced in those areas.

A related carbamate, oxamyl (Vydate), is labelled for use as a postbloom apple thinning compound in the northeastern U.S. I ts thinning activity is considered to be milder than that of carbaryl. H owever, it is disruptive of integrated mite control programs because it is toxic to predatory mites and other beneficial predators required in an integrated fruit production program. Robinson et al. (1998) suggest that $V y$ date could becombined with Accel for thinning. H owever, the efficacy of this combination has not been well-documented. Oxamyl combined with NAA is currently under test in W ashington for thinning spur ' $D$ elicious'. Although theinitial resultswith oxamyl and N AA as a postbloom thinning treatment are promising, the concern remains that integrated mitecontrol will be disrupted.

6-BENZYLADE NINE

(ACCEL, PROMALIN). The mode of action of synthetic cytokininsasfruit thinning agents is not understood. The metabolic activity of the fruit tissue may be altered due to the increased cell division rate stimulated by the cytokinin application. U nder northeastern conditions, the thinning and size enhancement responseto 6-BA has been documented in round-type apples such as ' $\mathrm{M} \mathrm{Cl} \mathrm{n-}$ tosh' (Greene and Autio, 1989) and 'Empire' (Elfving and Cline, 1993a). With spur 'D elicious', acultivar known for an elongated $L / D$ ratio, the thinning and size effects of 6-BA, marketed as Accel (Abbott $L$ aboratories, Chicago, III.) are weak or inconsistent at the currently labeled rate of 148 $\mathrm{g} \cdot \mathrm{ha}^{-1}(2.11 \mathrm{oz} / \mathrm{acre})$ of active ingredient. Asmuch as $247 \mathrm{~g} \cdot \mathrm{ha}^{-1}$ (3.53 oz) acre) of 6-BA per acre may be necessary to produce a thinning response in 'D elicious' (Elfving and Cline, 1993a; Greeneand Autio, 1994). In the PN W, the size enhancing effects of 6-BA are also fairly mild with 'D elicious' and 'Fuji', but have been dramatic with 'Gala' in some cases (R. Fritts, personal communication).

A nother advantage of 6-BA is its pronounced enhancement of return bloom by stimulating flower bud initiation and reducing excessive lateral shoot growth (E Ifving and Cline, 1993b; Greene and Autio, 1990). Although 6BA has been observed to stimulate lateral branch development in young trees, the application of Accel or Promalin at higher rates $\left(150 \mathrm{mg} \cdot \mathrm{L}^{-1}\right.$ 
also increases flowering. The application of 6-BA can occur over a wide range of time, from $80 \%$ full bloom until $\approx 10 \mathrm{~mm}$ (0.39 inch) fruit size. For Promalin, which is used mainly for affecting fruit type (shape), application from $80 \%$ full bloom until about petal fall ( 3 to $5 \mathrm{~mm}$ ) ( 0.12 to 0.20 inch) is recommended. Promalin has been observed to cause mild thinning under certain conditions, but its thinning effect has not been consistent. The optimum timing for Accel applicationsis at the 5 to $10 \mathrm{~mm}$ (0.20 to 0.39 inch) fruit size range. It is critical that the spray solution contacts the fruit, rather than the leaves, as uptake occurs primarilythrough thefruit surface ( $G$ reene and Autio, 1994). O ne of the negative interactions observed with Accel is increased formation of pygmy fruit in sensitive varieties such as spur 'D elicious' when NAA is applied either in combination with the Accel, or as a separate spray within a few days of Accel application (Greene and Autio, 1994). The cause of increased pygmy fruit formation from combinations of 6-BA and NAA is not understood.

The use of Accel for fruit thinning is fairly new to the apple industry, and much more experience on the producers' part will be required to establish its efficacy and practicality as part of a thinning program. It is certain that carbaryl will be necessary to enhance the fruit thinning effects of Accel (Greene and Autio, 1994). The drawback of 6-BA as a chemical thinning agent is its lack of performance under the growing conditions in the PNW, so its use in that region may be limited to small-fruited varieties such as ' $G$ ala'.

Gibbereluins. O ne of the components of Accel and Promalin is a proprietary mixture of gibberellins, specifically $\mathrm{A}_{4+7}$. Thegibberellinshave not been effective as pome fruit thinning materials, but have been used for their effects on fruit type (shape). G ibberellins elongate cells, rather than increase cell division (Edgerton, 1981). Gibberellins have been shown to be antiflowering in stone and pome fruit in the sense that flower initiation is reduced by exogenous applications of $\mathrm{GA}_{3}$ or $\mathrm{GA}_{4+7}$ (Southwick et al., 1995). Since $\mathrm{GA}_{4+7}$ Is present in low concentrations in both Accel and Promalin, flower bud initiation is promoted because of the 6-BA in the mixture (Greene and Lord, 1985). This positive effect on return bloom, despitethe presence of $\mathrm{GA}_{4+7}$ in these formulations, appears to be occurring in commercial orchards as well.

Ethylene (ethrel, ethephon). The mode of action of ethylene, or ethylene-releasing compounds, such as ethephon, is well understood. The high concentrations of ethephon applied during bloom or postbloom (generally 300 to $450 \mathrm{mg} \cdot \mathrm{L}^{-1}$ stimulate endogenous ethylene production. The ethylenethen promotes the formation of abscission layers in the pedicels of developing fruitlets. Like all of the plant bioregulators discussed in preceding sections of this paper, temperature plays a critical role in the degree of response to ethephon application (J ones and Koen, 1985). O ptimum temperatures for ethylene production and fruit thinning are in the 20 to 25 ${ }^{\circ} \mathrm{C}$ ( 68 to $77^{\circ} \mathrm{F}$ ) range. With temperatures in excess of $28{ }^{\circ} \mathrm{C}\left(82.4^{\circ} \mathrm{F}\right)$, which can occur occasionally in all apple producing areas in the U nited States, the risk of overthinning with ethephon has been a deterrent for its use as an early postbloom thinning material (R obinson et al., 1998; Williams, 1999). Drying conditions are also critical for ethylene generation after an ethephon application. It is recommended that a drying time of at least 4 to 6 hoursoccurs. $\mathrm{H}$ igh humidity increases the length of drying, and thus, uptake. Ethephon is not particularly selective in which fruit isremoved, unlike carbaryl or NAA which target the weaker fruit.

Fruit size at time of application does not appear to be as important for a fruit thinning response with ethephon as compared to N AA or carbaryl. Because ethephon is a nonselective fruit thinning material, a wide range of application timing from petal fall up to $20 \mathrm{~mm}$ (0.79 inch) is allowed. Generally, the earlier sprays of ethephon have been unpredictable in the degree of thinning, so mid $[10 \mathrm{~mm}(0.39$ inch)] to late [up to $20 \mathrm{~mm}(0.79$ inch)] application timing is generally preferred by apple producers. In N ew York, bloom and postbloom thinning treatmentswith ethephon are discussed in the production guide. Elfving and Cline (1993a) found that ethephon in combination with 6-BA increased postbloom thinning activity only slightly. Combinations of ethephon and 6-BA have not been adequately tested in the PN W.

Ethephon is commonly applied in combination with NAD to thin varieties such as 'Golden Delicious', 'Fuji' and 'Gala' in the PN W (Williams, 1999). Ethephon isused on spur 'D elicious' in the southeastern U.S. (C.R. U nrath, personal communication). H owever, ethephon applied to spur 'D elicious' in Washington causes flattening of the fruit, and reduced fruit size. N AD appearsto have anegative synergistic effect in combination with ethephon when used for postbloom thinning of spur 'D elicious'.

Ethephon is also used in young treesto promoteflower initiation (Williams, 1999). Application generally occurs 5 to 6 weeks after full bloom to avoid overthinning the current crop. 'Fuji' and ' $G$ ala' trees are responsive to early summer applications of ethephon after the postbloom thinning period, or generally $45 \mathrm{~d}$ after full bloom.

Williams and Edgerton (1981) described the many factors that affect apple thinning in both the northeastern and western U nited States. The effects of tree vigor, crop load, stress events and variety/ rootstock combinationsarenot to bediscounted. H owever, the common theme throughout this seminal publication is the importance of timing of application, proper concentration (rate) and environment (especially temperature and relative humidity) on the degree of postbloom thinning. The effects of temperature and light on the degree of postbloom thinning and carbohydratereserves for fruit development and subsequent flower initiation remain critical to the successful elimination of biennial bearing in apple. D espite the 50 or more years of research with postbloom thinning materials, pomologistsmust continue to learn about and master the art and science of chemical thinning. The authors would like to acknowledgethe considerable scientific and industry contributions made by pomologists such as J ack Batjer, M el Westwood, Louis Edgerton, Frank Dennis, and M ax Williams.

\section{Literature cited}

Byers, R.E., J.A. Barden, R.F. Polomski, R.W. Young, and D.H. Carbaugh. 1990. Apple thinning by photosynthetic inhibition. J. Amer. Soc. H ort. Sci. 115(1):1419.

Dennis. F.J. 1996. Thinning apples with Sevin. Proc. Mich. State H ort. Soc. 125:160-164. 
Ebert, A. and C.L. Kreuz. 1988. Chemical thinning of ' $G$ ala' apples in the state of SantaC atarina, South Brazil. ScientiaH ort. 36:229-239.

Edgerton, L.J. 1981. Some effects of aminoethoxyvinylglycine, 6-benzylamino purine and gibberellins on fruit set and vegetative growth of apple. Acta $\mathrm{H}$ ort. 120:125-130.

Elfving, D.C. and R.A. Cline. 1993a. Benzyladenineand other chemicalsfor thinning 'Empire' apple trees. J. Amer. Soc. H ort. Sci. 118(5):593-598.

Elfving, D.C. and R.A. Cline. 1993b. Cytokinin and ethephon affect crop load, shoot growth and nutrient concentration of 'Empire' apple trees. H ortScience 28(10):1011-1014.

Fallahi, E. 1997. Applicationsofendothallic acid, pelargonic acid, and hydrogen cyanamide for blossom thinning in apple and peach. H ortT echnology 7(4):18-22.

Fallahi, E., M.W. Williams, and W.M . C olt. 1997. Blossom thinning of 'Law Rome Beauty' apple with hydrogen cyanamide and monocarbamide dihydrogensulfate. J. Tree Fruit Prod. 2(1):33-44.

Fallahi, E., R.R. Lee, and G.A. Lee. 1998. Commercial-scale use of hydrogen cyanamide for apple and peach blossom thinning. H ortT echnology 8(4):556-560.

Grausland, J. 1981. Chemical thinning of the apple cultivar 'Summerred' with NAA and carbaryl. Acta H ort. 120:77-82.

Greene, D.W. and W.J . L ord. 1985. Effect of chemical thinners on 'D elicious' apple trees previously sprayed with $\mathrm{GA}_{4+7}+\mathrm{BA}$. $\mathrm{H}$ ortScience 20(1):84-86.

Greene, D.W. and W.R. Autio. 1989. Evaluation of benzyladenine as a chemical thinner on 'M clntosh' apples. J. Amer. Soc. H ort. Sci. 114(1):68-73.

Greene, D.W. and W.R. Autio. 1990. Vegetative responses of apple trees following benzyladenineand growth regulator sprays. J. Amer. Soc. H ort. Sci. 115(3):400-404.

Greene, D.W. and W.R. A utio. 1994. Combination sprays with benzyladenine to chemicallythin spur-type'D elicious' apples. H ortScience 29(8):887-890.

Greene, D.W., W.R. A utio, and P. M iller. 1990. Thinning activity of benzyladenine on several apple cultivars. J. Amer. Soc. H ort. Sci. 115(3):394-400.

Jones, K.M. and T.B. Koen. 1985. Temperature effects of ethephon thinning of apples. J. H ort. Sci. 60:21-24.

Lehman, L.J ., C.R. U nrath, and E. Young. 1987. Chemical fruit thinning response of spur 'Delicious' apple as influenced by light intensity and soil moisture. $\mathrm{H}$ ortScience 22(2):214-215.

Looney, N.E., M. Beulah, and K. Yokota. 1998. Chemical thinning of Fuji apple. Compact Fruit Tree 31(2): 55-57.

M icke, W.C., J.A. Grant, M.V. Norton, and J.T. Yeager. 1991. Thinning 'Granny Smith' apples chemically. Calif. Agr. 45(1):30-32.

Robinson, T., A. Lakso, E. Stover, and S. $\mathrm{H}$ oying. 1998. Practical thinning programs for N ew York. N .Y. State H ort. Soc. Fruit Q uarterly Publ. 6(1):14-18.

Schwallier,P.G. 1996. Applethinning guide. Great L akes Publishing Co., Sparta, M ich.

Southwick, S.M ., K.G. Weis, and J .T . Yeager. 1995. Controlling cropping in 'L oadel' cling peach using gibberellin: Effects on flower density, fruit distribution, fruit firmness, fruit thinning and yield. J. Amer. Soc. H ort. Sci. 120(6):1087-1095.

Westwood, M.N. and L.P. Batjer. 1960. Effects of environment and chemical additiveson absorption of napthaleneacetic acid by apple leaves. Proc. Amer. Soc. H ort. Sci. 76:16-29.

Williams, K.M. 1999. Growth regulator programs for chemical thinning of apple, $p$. 68-79. In: Crop protection guide for tree fruits in Washington. Wash. State U niv. EB0419.

Williams, M.W. 1993. Comparison of N AA and carbaryl petal-fall sprays on fruit set of apples. H ortT echnology 3(4):428-429.

Williams, M.W. 1994a. N ew chemical approaches for control of biennial bearing of apples, p. 16-25. Paul A. H edin (ed.). In: Bioregulators for crop protection and pest control. Amer. Chem. Soc. Symp. Ser. 557,205 th Annu. M eeting, D enver, C olo.

Williams, M.W. 1994b. Factors influencing chemical thinning and update on new chemical thinning agents. Compact Fruit Tree 27:115-122.

Williams, M.W. and L.J . Edgerton. 1981. Fruit thinning of apples and pears with chemicals. U .S. D ept. Agr. I nfo. Bul. 289. 